This is the version of the article accepted for publication in Political Geography published by Elsevier https://doi.org/10.1016/j.polgeo.2016.01.010

Accepted version downloaded from SOAS Research Online: https://eprints.soas.ac.uk/31016/

\title{
ETHNIC CLEANSING AND THE FORMATION OF SETTLER COLONIAL GEOGRAPHIES
}

\section{Authors: Neve Gordon and Moriel Ram}

Jon Stewart's The Daily Show was well-known for its left leaning political satire. Although the program focused on the United States, from time to time Stewart broadened the coverage and examined political events in other countries. Over the years, the policies adopted by the Israeli government had been among his satirical targets. A section dealing with Israel's 2014 military campaign in Gaza caught our eyes, since in the map suspended behind Stewart Israel's borders were not drawn according to the internationally recognized 1949 armistice agreements (Figure 1). The map is accurate in the sense that Israel's borders do not encompass the Palestinian West Bank and Gaza Strip, but its depiction of the Golan Heights as an integral part of Israel is flawed. The fact that Stewart's team chose this map is, however, hardly coincidental, since many existing maps have erased the line separating the Golan from Israel.

\section{Figure 1 about here}

Reflecting on the difference between the West Bank and the Golan Heights, two areas that Israel occupied in the June 1967 War, Meir Shalev, one of Israel's most popular authors, remarked that 'The holy sites of the West Bank represent today the pinnacles of lunacy, evilness and stupidity... The Golan, on the other hand, is the only normal territory we have left. It has no holy tombs, sites of religious frenzy or a large downtrodden and rebellious population' (Shalev 1994, emphasis added). Normal for 
Shalev means uncontested, familiar, or as one Israeli journalist once said, more Israeli than Israel itself (Shalev 2010). Nachum Barnea, a prominent Israeli journalist, offered an interesting account of why the Golan Heights became 'normal'. 'In the beginning there was fear', he wrote. 'The Syrian plateau posed a tangible threat to the [Israeli] valley. Then the remaining [Syrian] residents were removed. Their expulsion was necessary. The [Israeli] Labour movement does not occupy anything other than empty land; where the emptiness was not complete, it took care to make it complete...' (Barnea 1994). If one juxtaposes these two vignettes alongside the map used in The Daily Show then an important question arises: Did the removal of the Golan's Syrian population help produce its perceived Israeliness?

Building on existing research into ethnic cleansing, in the following pages we examine how the relative completeness or incompleteness of ethnic cleansing helps shape colonial geographies. We claim that there is a relation between the relative completeness of the ethnic cleansing and the type of settler colonialism that is produced. Relatively complete ethnic cleansing produces a 'refined' form of settler colonialism resembling the colonial geographies of North America and Australia and is characterized by the ability to normalize the contested space. In this form of settler colonialism, contradictions and excesses are less obvious since the indigenous population was almost completely cleansed and the landscape was reproduced through comprehensive destruction of indigenous spaces. By contrast, incomplete or less complete ethnic cleansing produces an 'intermediate’ form of settler colonialism similar to the colonial regimes in Rhodesia and South Africa before the settlers lost power and is characterized by a series of contradictions stemming from the settler's inability to totally prohibit the indigenous population's access to the territory-the primary objective of settler colonialism (Rose 1991). ${ }^{1}$ 
By ethnic cleansing we do not mean a genocidal campaign, but rather 'a purposeful policy designed by one ethnic or religious group to remove by violent and terror-inspiring means the civilian population of another ethnic or religious group from certain geographic areas’ (United Nations, 1994). Accordingly, the violence of ethnic cleansing is directed at emptying a space of certain populations (ethnic or religious groups) and has a spatial dimension that is vital to the definition of the violence. Genocidal violence, by contrast, focuses on the extermination of populations and its object is the human body, while the spatial dimension exists but is incidental. Interestingly, most of the scholarly literature has emphasized how ethnic cleansing is associated with the collapse of governing apparatuses, and is both a driving force and a product of human created catastrophes, but has dedicated only scant attention to the implicit objective of the cleansing: the effort to secure and normalize a new political order within a contested or colonized territory. Our claim is that the degree of ethnic cleansing is vital for understanding the new political order since the presence or absence of the "indigenous other" (Veracini 2008) helps determine the spatial and legal configurations produced within the territory where the cleansing took place. This, in turn, has an impact on the territory's normalization, where normalization means the construction of the space in question as ordinary, familiar and, indeed, uncontested in the eyes of the majority of the population whose side is responsible for carrying out the cleansing.

In order to advance this argument, we tap into the existing literature on settler colonialism. We espouse Patrick Wolfe's (1999, 2006) claim that settler colonialism is a structure, and embrace Caroline Elkins and Susan Pedersen's (2005) position that the structure is not homogeneous and can take on different forms and operate in diverse ways according to the circumstances that produced it (Elkins \& Pedersen, 
2005). Yet, unlike Elkins and Pedersen who highlight different structural manifestations of settler societies such as the level of settler control and settler privilege, we contend that the relative completeness or incompleteness of the ethnic cleansing plays a vital role in determining the particular makeup of the colonial geography and the legal framework that are introduced in the region. More precisely, the relative completeness or lack thereof of ethnic cleansing configures the actual structure - refined or intermediate - of the colonial geography by shaping 1) the specific way space is reproduced, and 2) the legal regime that is instituted within that space. It is important to add, however, that insofar that ethnic cleansing is not a 'oneoff occurrence' (Wolfe 2006, 388), then these settler colonial structures are to a certain extent fluid, changing overtime according to the quantity and proportion of the cleansing within a given period.

In order to uncover this less acknowledged—-because profoundly disturbingfeature of ethnic cleansing we compare two territories that were occupied by the same state during the same military campaign (the June 1967 War): the Syrian Golan Heights and the Palestinian West Bank. Out of a population of 128,000 Syrians living in the Golan Heights before the war, only 6,500 or five per cent remained in the territory after the war (Kipnis, 2013, 56-60). In the West Bank, by contrast, out of a population of approximately 850,000 before the war, about 600,000 or seventy per cent remained in the region in its aftermath (Ennab 1994; ICBS 1967 at Perlmann 2011). Focusing on the two intricately tied sites of social management—spatial reproduction and legal governance—-we argue that the relative completeness or lack thereof of ethnic cleansing not only shapes colonial geographies but also influences the ability to normalize colonial spaces. More specifically, we show how the scope of the ethnic cleansing carried out in the Golan Heights helped produce a refined form of 
settler colonialism, while the partial ethnic cleansing carried out in the West Bank produced an intermediate form of settler colonialism. The comparison of governing technics employed by the same state in the two territories that it occupied during the same war enables us to understand the impact of ethnic cleansing on settler colonial geographies and the forms of spatial and social management.

The paper is divided into four main parts. Following an overview of the literature on ethnic cleansing, we briefly outline our methodology. Next, we concisely compare the degree of ethnic cleansing carried out in the Golan Heights and West Bank. In the third and main part, we expose how the relative completeness or incompleteness of ethnic cleansing created two forms of colonial geographies: refined and intermediate. To do so, we compare the movement of settlers to each region, the lay out of the settlements and the modes of legal governance in the two regions. By way of conclusion, we examine the relation between the form of the colonial geography and its normalization.

\section{ETHNIC CLEANSING}

During the brutal and prolonged civil war in the former Yugoslavia (1992-1995), western commentators translated and popularized the Serbo-Croatian phrase 'etnicko ci scenje', thus rendering the term ethnic cleansing familiar to international audiences (Petrovic, 1994, 343). Notwithstanding the succinct definition provided above and the fact that ethnic cleansing is always achieved by violence, fear and terror, the reasons leading to its implementation, the way it is carried out, and the scope and extent of its execution vary greatly from case to case (Mann, 2005).

Ethnic cleansing can take place within a state or across international borders, and unfold within a short span of time or during a slow and painful process of 
expulsion (Bell-Fialkoff, 1996). Regardless of how, when, where and by whom ethnic cleansing is carried out, it is based on the premise that a certain ethnic group must be expelled from a certain space, while the space, in turn, is often reified as part of another ethnic homeland (Naimark, 2001). Expulsion, however, is only one aspect of the cleansing. Another prominent feature involves the intentional plan to wipe out any proof of the displaced population's presence. This is often achieved through the destruction of the latter's lived environment, and the erasure of any signs of their culture and history (Doel \& Clarke, 1998; Tyner 2014). As we show below, the ability to erase the culture and history and to reshape the geography is also dependent on the relative completeness of the ethnic cleansing that is carried out.

Ethnic cleansing also tends to be tied to settler colonialism, since this form of colonialism is premised on gaining access to territory by removing the 'indigenous other' from their land (Rose, 1991; Veracini, 2010; Wolfe, 1999), while the depleted area is often resettled by other ethnic groups. Settler colonialism may be carried out through the forceful relocation of the colonizing state's citizens, the movement of willful settlers, or a mixture of both (McGarry, 1998). Usually, the act of resettlement is conducted in order to prevent the return of the expelled population (Tuathail \& Dahlman, 2006). The settling act commonly aims to undo the demographic cavity that was created during the cleansing and is rationalized through a narrative that emphasizes a (frequently constructed) historical relation between the settlers' ethnic identity and the cleansed space (Kaufman, 2001).

Although the term only became widely used in the 1990s in relation to the Balkans, Nagorno-Karabakh (Rieff, 1997) and Rwanda (White, 2009), the concept of ethnic cleansing has gained significant traction as a growing number of scholars have applied it in their analysis of various historical events featuring forceful population 
removal. These, to name a few, include the expulsion of Native Americans from their indigenous lands (Anderson, 2005), the transfer of Ottoman Muslims from the Balkans (Mccarthy, 1995), and the displacement of European Jewry and Roma communities from various locations in Europe during the Second World War (Solonari, 2010). As Michael Mann cogently argued in his monumental study of ethnic cleansing and democracies (2005), ethnic cleansing is the outcome of the national drive to create a construable and controllable territory for a specific demos that is based on a specific ethnos. In addition, one finds a growing debate on the exact characterization of ethnic cleansing and its relation to other forms of systematic violence such as genocide, ethnocide or politicide (Sjoberg, Gill, Williams \& Kuhn, 1995).

Within this vast literature there is one crucial methodological observation that is particularly relevant to us. Following Tuathail and O’Loughlin (2009), we maintain that ethnic cleansing should be regarded as a form of geopolitics that strives to shape an existing spatial order (see also Wood, 2001). We accordingly propose that the relative completeness or lack thereof of ethnic cleansing informs the structure of a settler colonial regime since it influences the production of space, the forms of population management (Foucault and others 2009) and the structures of violence that are imposed, thus providing an explanation why in different regions different biopolitical techniques are imposed. Different degrees of ethnic cleansing, in other words, tend to produce different colonial geographies and biopolitical regimes.

By biopolitics (Foucault 2003) we mean a form of governance that operates on the population as a whole. Biopolitics does not replace the deployment of sovereign or disciplinary power, but as opposed to the latter it operates on a different scale while applying a series of distinct instruments. It too is continuous and spread out, but if 
discipline seeks to administer the individual subject, biopower manages the individual only insofar as he or she is a member of a population. Biopower employs an array of institutions that coordinate and regulate medical care, welfare services, the economy, and so forth, while configuring and circumscribing the political sphere and normalizing knowledge. In order to manage the population, biopower uses statistical devices and scientific methods as well as mechanisms of surveillance. It measures and intervenes in a set of processes relating to mortality rate, longevity, the fertility of the population, hygiene, vaccinations, prevalent illnesses in a population, birth rates, unemployment rates, the distribution of labor in terms of age, gender, and sectors of occupation, per capita income, and so on. Our claim is that the relative completeness or incompleteness of the ethnic cleansing and demolition of the built environment, which are forms of sovereign violence, shaped the ways through which biopolitics was exercised in each region.

We exemplify our claim by drawing on a large corpus of empirical evidence about Israel's occupation of the Golan Heights and the West Bank. Our sources include archival material from The Israeli State Archive (ISA), the Israeli Defence Force Archive (IDFA), the Central Zionist Archive (CZA) and the Golan Archive (GA) as well as the 1967 census carried out by Israel in the West Bank a few weeks after the war. In addition, we examined scores of military, United Nations and human rights reports published from 1967 onwards, and perused the archives of four daily newspapers: Davar, Ha'aretz, Yediot Achronot and Ma'ariv as well as several public opinion polls. Finally, we also use the findings and insights of the massive body of scholarly literature that has been published on these two regions over the years. 


\section{ETHNIC CLEANSING IN THE GOLAN HEIGHTS AND THE WEST}

\section{BANK}

While our analysis focuses on the period that followed the 1967 war, the ensuing investigation cannot be adequately understood without acknowledging the link between Israel's policies in the West Bank and Golan Heights and the ethnic cleansing that took place during and in the aftermath of the 1948 war (Abu-Lughod, 1971; Khalidi, Elmusa, \& Khalidi, 1992; Sa'di \& Abu-Lughod, 2007). It was then that about 750,000 out of 900,000 Palestinians who were living in what became Israel either fled or were forcefully displaced across international borders (Morris, 1987; Pappe, 2006). Several researchers have discussed the removal of Palestinians from the space that became Israel (Falah, 1996; 2003) and situated the act within the larger context of Zionist ideology (Shafir and Peled, 2002) and the Judiazation policy that guided Israeli decision-makers (Rishmawi, 1987; Yiftachel and Rumley, 1991).

This policy included several components, including the expropriation of Palestinian land and confinement of the Palestinians that remained in Israel into demarcated and circumscribed areas (Falah, 1991; Yiftachel \& Yacobi, 2004; Forman \& Kedar, 2004; Shai, 2006; Robinson, 2013). Scholars further stress Israel’s effort to preserve a viable ethno-centric democratic regime, which some have defined as an ethnocracy (Yiftachel, 2006) and others as a colonial democracy (Gordon, 2010). Hence, the spatial reconstruction of Israeli space before 1967 was already based upon a settler colonial paradigm whereby the indigenous other is reduced to a 'manageable' remnant (Veracini, 2011).

It is, accordingly, not altogether surprising that when Israel occupied the Golan Heights (or the Syrian plateau, as it was referred to in Israel at the time), it dramatically reduced the indigenous population (Harris, 1978; Ram, 2013; 2015). 
Israel's main tactic was intimidation and, occasionally, forceful removal of the civilian population who remained in the Golan after the fighting subsided (Harris, 1980; Murphy \& Gannon, 2008). Furthermore, Syrian residents of the area who were caught attempting to return to their villages were brought before a military tribunal and deported (IDFA, 1967a). Thus, within a couple of months after the Golan Heights' occupation only 6,404 Syrians remained in an area that had been populated by about 128,000 people before the war (Kipnis, 2013: 56-60; IDFA, 1967b; ISA, 1967a), indicating that almost 95 percent of the population had been removed. This created the conditions for implementing a refined form of settler colonialism and, as we will see, the introduction of more liberal biopolitical techniques of population control, by which we mean, following Foucault, less interference, allowing free movement, and letting things 'follow their course so that the [colonial] reality develops and follows its own course according to the laws, principles, and mechanisms of the reality itself' (Foucault and others 2009 p. 70). Liberal bioplitical techniques, as Foucault underscores in a different context, can be a correlative of the deployment of apparatuses (dispositif) of security, where security means the management of the life of populations as opposed to disciplinary practices that are exercised on the bodies of individuals.

By contrast, an estimated 850,000 Palestinians lived in the West Bank before the 1967 war (Ennab 1994; based on extrapolation from the 1961 Jordanian census), while an Israeli census, carried out in the summer of 1967 indicates that 599,000 Palestinians were still in the region after the war (ICBS 1967 posted in full at Perlman 2011). Accordingly, approximately 250,000 inhabitants or thirty percent of the population fled or was expelled to Jordan during the 1967 war and its direct aftermath, while only 17,000 were ultimately allowed to return (Gazit, 1995). Hence, 
in this area the form of settler colonialism that was produced was intermediate and, as we will show, the biopolitical techniques that were utilized were predominantly illiberal.

We now turn to demonstrate how the difference in the degree of ethnic cleansing shaped the two colonial geographies by outlining the differences in the production of space and the character of the legal regime in each region.

\section{ETHNIC CLEANSING AND COLONIAL GEOGRAPHIES}

\section{Spatial Reproduction}

The production of space in the Golan Heights commenced through a process of wholesale destruction, as is often the case in refined forms of settler colonialism. Immediately after the war, a list of abandoned Golan villages designated for preservation was compiled by the Israel Nature Reserves Authority and handed over to the Land Authority (ISA, 1967a; ISA, 1967b; 1968a). Of the 139 Arab agricultural villages and 61 individual farms registered prior to the war, only seven villages were designated to remain (GA, 1967; IDFA, 1967a). The almost complete removal of the Syrian population from the Golan Heights during the war created the conditions for the systematic demolition of these villages, farms, and houses, while the extensive destruction facilitated the reproduction of space. This initial act of destruction was similar to the destruction of Palestinian built environment after the 1948 war and the shaping of Israeli landscape in the pre-1967 borders (Leshem, 2013). In other words, the Golan's landscape underwent a process of "violent erasure" (Tyner 2014) because, as Patrick Wolfe $(2006,388)$ points out, 'Settler colonialism destroys to replace'.

Unlike the Golan Heights, the West Bank remained populated and therefore the extent of destruction during and in the immediate aftermath of the war was 
considerably more restricted characterizing, as it were, an intermediate form of settler colonialism. According to Israel's 1967 census-except for the three villages in the Latrun enclave, several hamlets, as well as refugee camps in the Jordan valleyalmost all of the over 300 Palestinian villages, refugee camps and towns were not fully vacated (ICBS 1967 posted in full at Perlman 2011), and remained standing after the war. Avi Raz (2012: 103-136) does, however, document several instances of spatial destruction. More than 40 percent of Qalqilyah’s dwellings—some 850 houses_-had been demolished, while in Zeita, a village located near the Green Line, about one-third of the buildings were torn down. These examples of demolitions were part of a broader policy aimed at clearing the area adjacent to the western border of as many inhabitants as possible. Even though Israel ended up destroying hundreds if not thousands of houses, almost all of the towns and villages close to the border ultimately remained intact due to the fact that they were not completely depopulated.

The demolitions in each area served different purposes. In the West Bank the destruction was carried out primarily in order to propel the population to leave certain areas; and, in the case of the Latrun enclave, in order to ensure that those who had been expelled would not return. In the Golan Heights, it was executed not only in order to guarantee that the Syrian population would never return but also in order to shape the colonized space in a new way. More importantly, the varying degree of demolition not only had a direct effect on the colonial geography of each region, but also on the legal framework and biopolitical technologies that were introduced. Insofar as the establishment of settlements and the relocation of settlers to colonized spaces are techniques of biopolitics (as we show below), then one can also appreciate how ethnic cleansing determines the settling processes and in this way partly shapes the biopolitical regime that is instituted. 
The Golan Heights was the first of the territories to be settled by Israeli civilians after the June 1967 war. As early as July of that same year, a group of settlers from the Labour Party affiliated United Kibbutz Movement moved into abandoned Syrian barracks (Gorenberg, 2006: 72-98). Within the next decade and a half, 30 settlements were established housing several thousand Jewish settlers (currently there are 34 settlements). In the West Bank the colonization process also began not long after the war. During the first years, three kinds of settlements were created: civilian military bases (i.e., military outposts that were established on Israel’s frontiers and gradually converted into civilian agricultural communities), religious settlements and neighbourhoods in East Jerusalem (built on land that had been an integral part of the West Bank prior to the war). Military bases were established in the Jordan Valley and other strategic sites and were later converted into civilian settlements, usually populated by secular Jews affiliated with the Labour Party (Zertal and Eldar, 2007). These were considered strategic settlements. Religious settlements were created in the heart of the West Bank. These were considered political settlements, since in contrast to the strategic ones the motivation behind them is not military but rather messianic (Zertal and Eldar, 2007). Thirdly, Israel built Jewish neighbourhoods in East Jerusalem in order to undermine the city's east/west divide and alter the demographic balance between Jews and Palestinians in the city (Mattar, 1983).

By the late 1970s, Israel initiated a fourth kind of settlement often referred to as 'suburban settlements', catering to middle-class Israeli citizens who worked in urban centres and wanted to improve their lifestyle (Newman, 1996). And, then, in the early 1990s it founded two ultra-orthodox cities in the West Bank (Mnookin \& Eiran, 2005). It was precisely these two newer types of settlements that attracted the post- 
Oslo mass movement from Israel proper to the West Bank (Gordon \& Cohen, 2012). Finally, at the dawn of the new millennium religious settlers began creating outposts throughout the West Bank, and while most outposts house only few people they actually substantially improve Israel's control of the occupied territory (Mnookin \& Eiran, 2005; Sasson, 2005) (more on this below). Currently, there are about 120 Jewish settlements and about the same number of outposts in the West Bank (Peace Now Settlement Watch).

While it may appear intuitive that the production of empty land-through the depopulation and wholesale destruction of the Golan Heights--would lead Israel to build more settlements in that region, actually at least four times as many settlements were built in the West Bank, a difference that becomes crucial insofar as settlements are not merely architectural edifices but part of a biopolitical regime aimed at managing the indigenous other. Hence, the different degree of demolition in each territory had a profound impact on the colonial geographies as well as on the legal framework and biopolitical techniques employed by the state.

\section{Settlers}

The variance relating to the number of settlers in each region is also worth noting. In 2013, 21,000 settlers lived in the Golan Heights (ICBS Statistical Abstracts 2014), while in the West Bank there were 356,000 settlers (ICBS Statistical Abstracts 2014) and an estimated 200,000 in occupied East Jerusalem (Gordon and Cohen 2012). Two reasons are usually offered to explain the disparity between the two settlement projects: eschatological and geographic. Unlike the Golan, the West Bank is believed to be the heart of the biblical land of Israel and certain sectors among the religious Jewish population considered Israel's victory in the 1967 war as the 'beginning of 
redemption' and as an opportunity to realize the vision of a Greater Israel through a massive settlement project (Feige, 2009). Geographically, the Golan Heights—when compared to the West Bank-is far from Israel's economic centre, and it is presumed that the distance serves as an obstacle for relocating a large number of people to that region (Kipnis, 2013).

The West Bank's eschatological importance and its geographical proximity to the centre of Israel surely help explain the quantitative difference between the two settlement projects. But we would like to add that ethnic cleansing also explains the difference in settler population in the two regions. In the Golan Heights, the indigenous population does not have the required mass to mount an effective separatist campaign, and the transfer of 21,000 settlers was enough to secure a demographic balance in the region. Therefore, the state has had less incentive to transfer more citizens to the Golan. By contrast, in the West Bank the movement of large numbers of settlers was consciously geared towards countering the will of the indigenous Palestinians to establish their own state within this region (Ministry of Agriculture, 1983), while simultaneously the Jewish settlers have been usedwittingly or not—as a civilian technology of biopolitical control (Gordon 2008).

While one might assume that ethnic cleansing would spur the relocation of population from the core state to the 'empty territory', the two cases suggest that an opposite dynamic can also materialize: the existence of an indigenous population can also drive the core state to transfer its citizens to the newly colonized region. Hence, at least in the Israeli case the degree of ethnic cleansing has had an inverse impact on the efforts of the core state to settle it. Insofar as the settler population is conceived of as a technology of indigenous control (and not merely a vehicle for exploiting resources) then the more a space is depleted of its indigenous inhabitants, the less the 
effort to populate it. It is here that one can identify a direct link between the policies within the Green Line and the post-1967 colonized areas. As mentioned, throughout the 1960s and 1970s the government made a concerted effort to move Israeli Jews to the Galilee where Palestinians (who remained following the 1948 war) had large a majority (Falah, 1989, 1991), but at the time there was less of an effort to settle the Negev because its Bedouin population had been depleted during and after the war from an estimated 110,000 to 11,000 people (Nasasra, 2012). Currently, however, the effort to Judaize the Negev has accelerated not least because the birth rate of the Bedouin population is very high and the population has increased substantially to over 220,000 (ICBS Statistical Abstracts 2014). Put differently, the same colonial rationalities that shaped Israel's internal frontiers after 1948 (Yiftachel and Segal, 1991) were also evident in the territories the state colonized after 1967.

\section{Colonial settlements}

Not only the settler population and the number of settlements, but also the layout of the settlements across the terrain and even the architecture of the buildings has been informed by the act of ethnic cleansing. In the Golan Heights, the layout of the settlements was initially determined by economic considerations (Harris, 1980; Efrat, 2012; Kipnis, 2013). Kibbutzim were erected mainly in the north and moshavim in the south where the terrain was more conducive to agriculture (Ram, 2015). Only at a later stage were a number of settlements established in the region's centre and close to the border where agriculture was limited due to the topography.

Freddy Kahana, the architect who planned kibbutz Merom Golan, the first settlement established on the Golan Heights, said in a 2000 interview that people initially wanted to build the kibbutz on top of a volcanic hill, but he decided to embed 
the kibbutz in the 'earth as close as possible to the slopes' and in this way shield the built environment from possible Syrian shelling (Azoulai, 2000; see Figure 2).

Kahana explains:

Merom Golan was definitely not based on the idea of a fortress. It was a normal settlement, in normal conditions whose defences are not in its own hands. The region was not hostile, the enemy was located five kilometres from the border, and facing the enemy there were a series of Israeli tanks. We did not establish a settlement with a wall around it that could be counted on to defend itself with a few guns; we just thought how people and children could reach a shelter if the settlement was shelled (Azoulai, 2000, 45).

Kahana's underlying assumption is that the Golan Heights is empty of an indigenous other. The enemy he refers to are the Syrians who are located across the international border. Hence, the settlement is not conceived as a biopolitical technology aimed at managing or controlling an indigenous population. Moreover, the Golan’s open landscape devoid of checkpoints is characteristic of a refined form of settler colonialism.

\section{Figure 2 about here}

The function of settlements in the West Bank has been very different. Unlike Merom Golan, they were almost always built on hilltops overlooking Palestinian villages (note that the topography of the two regions is also different) so that they could serve 
as mechanisms of civilian surveillance (B'Tselem, 2002). In and of themselves the settlements' built-up areas comprises less than two percent of the West Bank, but their regional and municipal boundaries comprise almost 42 percent of the land. These boundaries were created to restrict Palestinian movement and undermine their development. Simply put, Palestinians are banned from using 'settlement land' for agriculture or for extending their lived environment, and they are even prohibited from entering large parts of this area, thus hindering their ability to move freely even within the West Bank (Ibid: 116). Already in 1980, the settler movement explained that '[Their] control of a region is a function not only of the size of the population which resides within the region, but also of the size of the area in which this population exercises its influence’ (Ministry of Agriculture, 1983).

The settlements in the West Bank have provided, according to Eyal Weizman (2007: 139-161), three strategic assets: greater tactical strength, self-protection, and a wider view. The distribution, layout, and architectural design of the settlements were determined by strategic military principles so that, in Weizman's words, the "simple act of domesticity, a single family home shrouded in the cosmetic façade of red tiles and green lawns, conforms to the aims of territorial” and social control. The settlements’ strategic function was integrated into their distribution and topographical location so that they created a 'network of observation' that overlooks the main traffic arteries of the West Bank (Segal et al., 2003 pp. 85-86). The desire to maximize the visibility of the indigenous Palestinian population dictated the mode of design of the settlements, down to the positioning of windows in houses, thus transforming settlements into 'optical devices, designed to exercise control through supervision and surveillance’ (Segal et al., 2003 p. 24). 
The West Bank’s colonial geography is, accordingly, made up of biopolitical artefacts that aim to render the occupied inhabitants visible and docile. The settlements are used to monitor the Palestinians who work in the fields below or travel on the adjacent roads and in this way function as panoptic towers. Indeed, as Ariel Handel (2013) demonstrates, the roads connecting the settlements also function as a complex mechanism of social control. Ironically, the settlements and roads are a more exact model of Foucault's notion of surveillance than the panoptic tower (the example he uses) since their gaze is not centralized; like Foucauldian power they are not located in one identifiable site but are rather capillary, scattered throughout the terrain supervising the local inhabitants from numerous spots (Foucault, 1977).

Finally, it is important to mention that as is often the case with intermediate forms of settler colonialism, the West Bank's landscape is riddled with checkpoints, concrete blockades, and dirt mounds, while a 617 kilometre barrier separates between the colonized territory and pre-1967 Israel (Sorkin 2005). The significance of these obstacles in the context of this article is that the rationale justifying the deployment of checkpoints and the construction of the barrier (which are, in and of themselves a form of violence) was the need to protect Israeli Jews from the indigenous other (Amir 2013). Part of the West Bank barrier was built on the international border, but part of it was built deep inside the colonized Palestinian territory. Hence, the barrier is also a technology for expropriating Palestinian land, as it cuts-off Palestinians from their agricultural fields, schools, work place, and hospitals (Hatuka 2012). It is a prime example of how the degree of ethnic cleansing continues to inform the production of space and the structures of violence even decades after the cleansing was carried out. In this sense, it corroborates Simon Springer's (2009) claim that acts of violence are not limited to enclosed and delimited places or restricted to a 
circumscribed time. Indeed, ethnic cleansing, like other forms of violence, not only occurs within place and supersedes place, but also helps determine the (re)creation of space over an extended period of time.

This cursory comparison reveals how the completeness or lack thereof of ethnic cleansing in each area determined the function of the settlements (and roads), governed the way in which they were laid out, their topographical setting, and even the design of the architectural edifices within and outside the settlements. In the Golan Heights, the settlements' location was determined primarily by economic concerns and issues relating to topographic access and the position of an external enemy (i.e., Syria) and were never conceived as a biopolitical technology developed to control the indigenous population. By contrast, in the West Bank, settlements were designed as biopolitical tools aimed at facilitating control of large swaths of land and monitoring the indigenous Palestinians. Interestingly, the spatial configuration of the settlements in the West Bank was shaped according to similar parameters that guided the establishment of mitzpim and towns in the Galilee between the 1950s and 1970s. For example, the town of Kiryat Arba that overlooks Hebron was modelled on the Jewish town Upper Nazareth, located above the Palestinian city in the Galilee (Zertal \& Eldar, 2007, 22).

\section{Rule of law and modes of governance}

Following the war, Israel reinstated the Ottoman, British Mandatory, Egyptian, and Jordanian laws that had been in place prior to the war in each of the regions it had captured, and over the years, added an array of military orders either to replace existing laws or to add new ones (Ben-Naftali, Gross and Michaeli, 2005). The difference between the Golan Heights and the West Bank is that in the former, where 
ethnic cleaning was almost complete, the military commander focused on lawmaking, issuing decrees that de facto imposed Israeli civilian law on the Golan and almost completely ignored the Syrian laws that existed prior to the occupation (Murphy and Gannon, 2008). In the West Bank, where most of the indigenous population had remained put, we witness the importance of law-preserving; a decree imposing civilian law was never issued, and the Ottoman and Jordanian laws were used alongside military orders (Gordon 2008).

Hence, there appears to be a relation between the degree of ethnic cleansing and the precise configuration of law-preserving and law-making in the colonized space (Benjamin 1978). The rationale informing the application of civilian law through military decrees in the Golan Heights (law-making), which was part of the normalization strategy, was grounded in the assumption that the Golan Heights was an empty space, free of inhabitants. As a way of justifying the law-making strategy official representatives claimed that the Golan Heights had had in place only minimal governmental or legal provisions (Levi, 1982: 104). The claim about the absence of law in the Golan echoed the notion of 'emptiness' referred to in the beginning of this article and helped obfuscate the very dynamic that transformed the plateau into a space with no trace of rules.

In the West Bank, there was no intention of incorporating the residents into Israel proper (the pre-1967 borders) because the 600,000 Palestinians residing in the region threatened the Jewish demographic majority that the Zionist leadership was determined to preserve. Consequently, Israel never imposed its own civilian laws on the Palestinians inhabitants and instead used Ottoman and Jordanian laws as well as literally thousands of orders issued by the military commander to manage them (Shedadah, 1985). Israel also established military courts as opposed to the civilian 
courts in the Golan (Hajjar, 2005: 132-154). This law-preserving and law-making military legal system served as the foundation for almost all of the governing apparatuses and practices and in many ways shaped their operations (Gordon, 2008).

Each legal system was established according to the degree of ethnic cleansing, while it, in turn, shaped the modes of governance that were established in the two colonized territories. Generally speaking, when a large proportion of the population within the colonized area is indigenous, we can expect the imposition of a less liberal legal system and biopolitical technologies. This is also what characterizes an intermediate form of settler colonialism, as opposed to a refined one.

Unlike the Palestinians in the West Bank, the Syrian Druze, were immediately allowed to become Israeli residents and received many benefits associated with full citizenship. By February 1968, the permit regime in the Golan was considerably eased. Syrian residents no longer needed formal authorization to enter Israel or move, and were allowed to sell their agriculture products to Israelis without governmental mediators while their wages were made commensurate with their Israeli counterparts (Haaretz, 1967; Dar, 1968). In addition, the Golan’s residents were incorporated into the national health insurance and social security schemes and they enjoyed a series of political rights such as the ability to join different organizations like trade unions and political parties (Dar, 1973).

For the first fourteen years the Syrian Druze continued to live under a military government, which occasionally confiscated their lands and deployed coercive strategies like administrative detention, but was nonetheless much more liberal than the military government in the West Bank. ${ }^{2}$ As one reporter declared in 1971 'the military government [in the Golan Heights] was so far the most liberal of all the [Israeli] military governments in the [occupied] territories. It has respected the Druze, 
allowed them total freedom of movement and provided them with vocational opportunities inside Israel, supplied electricity to the villages, paved roads and provided health services’ (Tzidkoni, 1971). Because only a few thousand Syrians had remained on the Golan they did not constitute a demographic threat to the Jewish character of the State. Consequently, Israel was ultimately willing to pay the price of granting them citizenship in exchange for normalizing the incorporation of the region into the state. In December 1981, Israel unilaterally annexed the Golan and formally extended its own civilian law (this time not through military decree) to the Syrian residents who were then offered full citizenship even though, at the time, most of them declined to accept it (Yishai, 1985). The forms of control deployed in the Golan Heights and the process of integration of the Syrian residents were very similar to the processes used in relation to Palestinians within Israel following the 1948 war and characterize a refined form of settler colonialism. Not unlike the Palestinians within the pre-1967 borders, the Syrian Druze in the Golan were placed under a military rule that slowly integrated them within the state apparatus, and they too were offered an opportunity to obtain a formal, yet in some respects nominal, Israeli citizenship (Robinson, 2013; Sa'di, 2013).

In the West Bank there was never any intention of incorporating the population into the Israeli demos. Accordingly, the population was managed through a military bureaucratic apparatus and did not enjoy many of the basic rights granted to Israelis or even the occupied Syrian population, such as the right to freedom of movement, speech, and association (Gordon 2008). Since we cannot really capture the modes of governance deployed in the West Bank in this article, we will only note that Israel established in this region an elaborate permit regime, not unlike the one implemented in South Africa (Dayan, 2009), which was characterized by its 
ubiquitous nature, creating a grid that extended across every part of Palestinian life, leaving no space untouched.

The permit regime, for example, restricted movement and helped constrain the development of an independent Palestinian industry and agriculture and impeded Palestinian construction (Military Orders and Proclamations 1967-2014: 65, 88), operating also in complex ways to ensure that Palestinian workforce would be made up of mostly unskilled labour (Roy, 1995). It is in this context that we should mention that our earlier claim about Israeli civilian law never being imposed in the West Bank is not entirely accurate. The Jewish settlers, who currently comprise about nine percent of Israel's Jewish citizenry (Gordon and Cohen 2012), are extraterritorial citizens who, like diplomats, carry Israeli law on their back. In other words, Israeli civilian law is imposed in the West Bank but only in relation to the Jewish settlers. Thus, as opposed to the Golan Heights where there is one set of laws that is applicable to all the people, in the West Bank two legal systems operate simultaneously, one for the Palestinian inhabitants and the other for Israeli citizens. This, again, characterizes an intermediate form of settler colonialism and produces an obstacle for Israel's efforts to normalize the colonial project.

This structural difference between the two colonial projects is informed by the degree of ethnic cleansing carried out during the war. The legal duality in the West Bank sustains the difference between settler and indigenous inhabitants and consequently Israel's colonial project in this region is both apparent and cannot supersede itself. By contrast, in the Golan Heights the distinction between the colonizer and colonized is legally obscured, and this alongside the reproduction of space helps obfuscate the colonial reality and thus helps normalize Israel's colonial project in this region. It is not a coincidence that most of the scholars (e.g., Gordon, 
2008; Veracini, 2008; Veracini, 2011; Wolfe, 1999; Wolfe, 2006; Yiftachel, 2006) who have examined Israeli settler colonialism have hardly even mentioned the Golan Heights.

\section{CONCLUSION: NORMALIZATION AND FORMS OF SETTLER}

\section{COLONIALISM}

While our case study has its unique traits (like all case studies do), it reflects two different prototypes of settler colonial structures, which we have characterized as refined and intermediate. In the refined form of settler colonialism, the contradictions and excesses are less apparent since the indigenous population was completely or almost completely cleansed and the landscape was reproduced through comprehensive destruction of indigenous spaces (for an example of the inability to completely erase the materiality of the indigenous past see Tyner, Alvarez \& Colucci, 2012; for a specific discussion regarding the Golan Heights see Ram, 2015). Intermediate settler colonialism is characterized by a series of contradictions because, as we mentioned in the introduction, the access to the territory - the primary objective of settler colonialism - is never complete so long as the indigenous population stays put. Accordingly, intermediate settler colonialism is informed by two oppositional forces. The elimination drive (Wolfe, 2006), that aims to finalize the settler colonial project by doing away with the indigenous population and thus rendering the whole territory accessible — a refined form of settler colonialism. And the repelling drive, characterized by indigenous resistance aimed at forcing the settlers to retreat- the intermediate form. The struggle between these oppositional forces continuously exposes the settler project for what it is, thus rendering it difficult to achieve normalization. 
Among Israel's citizenry the relation to each territory is indeed very different even though both regions were colonized during the same war. In a 1974 public opinion poll, 86 percent of the Jewish population regarded the Golan as 'too important' to be returned, and believed that the government should finance the Golan's settlement project. In the West Bank, by contrast, the same poll revealed that only 45 percent supported the colonization project (IDFA, 1974), this despite the fact that religious Jews consider the West Bank to be part of the biblical land of Israel while the Golan has hardly any biblical significance. In a poll carried out almost four decades later, in 2012, over 75 percent of Israeli Jews either strongly disagreed or moderately disagreed with the question: 'In the framework of a peace agreement that includes appropriate security arrangements, the Golan Heights could be returned to Syria’. By contrast, only 38 percent of Israeli Jews either strongly disagreed or moderately disagreed with the question: 'In the framework of a peace agreement that includes appropriate security arrangements, one should agree to the establishment of an independent Palestinian state' (Peace Index, 2012).

These polls reveal that for many Israelis the Golan Heights has come to be regarded as an integral part of Israel, so much so that for them the colonial project has been supplanted. The fact that the colonization project was erased from the map hovering over Jon Stewart (as well as from scores of other maps) underscores that the colonization of the Golan Heights has been normalized. The ability to normalize colonial violence and render it invisible is, we maintain, the outcome of the refined form of this settler colonial structure.

There are many reasons why Israel's colonial project in the West Bank has remained intermediate and resisted normalization, but they all have to do with the fact that the ethnic cleansing in this region was only partial. While the reproduction of the 
colonial landscape is vital, perhaps the major reason why many Israelis still do not consider the West Bank as an integral part of Israel—even after the state transferred over half a million citizens to this swath of land-is their fear that if its Palestinian inhabitants were to be incorporated as citizens into the state they would undermine the Jewish demographic majority and threaten the state's Jewish character (Smooha, 1997). Insofar as this is the case, then the aspiration for racial purity among Israeli Jews ultimately trumps the desire for territory.

Other factors also play an important role. Israel considers itself as a democratic regime and the ongoing effort to control a territory inhabited by another people through military decrees while not offering them citizenship undercuts its democratic pretensions (Shafir \& Peled, 2002). By contrast, the Golan Heights was legally incorporated into Israel precisely because it was almost completely depopulated from the 'indigenous other'. Moreover, the normalization process could proceed because the land was regarded as empty and the colonial project was never considered to have entailed expropriation and confiscation. Hardly any Syrian villages and towns 'contaminate' the landscape and therefore there is no permanent reminder of a precolonial existence, while the few remaining indigenous inhabitants did not constitute a demographic threat and consequently were granted citizenship and with it liberal rights.

Although the relative completeness or lack thereof of ethnic cleansing in the West Bank and the Golan Heights helped shape the settler colonial geographies in each region (one intermediate and the other refined), we maintain, following Wolfe, that these prototypes are never static. The act of ethnic cleansing itself as well as the demographic proportion between settler and indigenous continue to change. So although we have claimed that the difference between the Golan and the West Bank 
can be traced back to the ethnic cleansing (complete/incomplete) during the 1967 war, a more precise argument would acknowledge that there is a dynamic relation between the degree of ethnic cleansing and the legal-spatial order producing the settler colonial geography. Having said this, the central and indeed extremely disturbing point still stands: the degree of ethnic cleansing shapes the structure of colonial geographies. 


\section{Notes}

1 Like all binary typologies in the social sciences, these too represent ideal types.

2 After the June 1967 war, only six villages remained intact in the Golan Heights: Majdal Shams, Mas'ade, Buq'ata, Ein Qiniyye, Shayta and Ghajar. Syrian Druze populated all of these localities, except Ghajar (IDFA, 1967a). In addition, the Syrian Druze were the only residents that were allowed to return (ISA, 1969). The reason for this was that Israel considered the Druze to be more "friendly" population to its rule. An assumption that was based on the form of repor that developed between Israel's state authorities and its own Druze citizens. For a discussion on the fate of the Syrian population from the Golan who fled to Syria see Abu Fakhr, 2007; Szanto, 2012. For a discussion on the convoluted relationships between Druze and the Israeli state see Firro, 1998. 


\section{References}

Abu Fakhr, S. 2000. Voices from the Golan. Journal of Palestine Studies, 29(4), 5-36.

Abu-Lughod, I. A. 1971. The transformation of Palestine: Essays on the origin and development of the Arab-Israeli conflict. Evanstone, IL, USA: Northwestern University Press.

Amir, M. 2013. The making of a void sovereignty: political implications of the military checkpoints in the West Bank Environment and Planning D: Society and Space 31(2), 227-244.

Anderson, G., C. 2005. The Conquest of Texas, Ethnic Cleansing in the Promised Land, 1820-1875. Norman, OK, USA: University of Oklahoma Press.

Avni, I., \& Petersburg, O. 2007. Mokshim Ba-Rama (mines in the heights). Yediot Achronot, 11 November 2007 (Hebrew).

Azoulai, A. 2000. How does it look to you? Tel Aviv, Israel: Babylon (Hebrew).

B’tselem, 2002. Land Grab, Israel's Settlement Policy in the West Bank, Jerusalem, Israel: B’tselem publishing house.

Barnea, N. 1994. Lo Mechakim Le Rabin (not waiting for Rabin). Yediot Achronot, 9 September (Hebrew).

Bell-Fialkoff, A. 1996. Ethnic Cleansing as a normative solution. New York, NY, USA: St. Martin's Press.

Benjamin, W. 1978. "Critique of Violence," in Reflections. New York, NY, USA: Schoken Books, 277-300.

Ben-Naftali, O., Gross, A., and Michaeli, K., 2005. Illegal occupation, Framing the occupied Palestinian territory. J.Int'l Law, 63, 551-614.

Central Zionist Archive (CZA). 1969. KKL5/31273, "Afforestation efforts on the Hermon", March 1969. 
Chief Military Command. 1972. Orders and Proclamations, Judea and Samaria, 1968 - 1972. Tel-Aviv, Israel: Israeli Defense Ministry (Hebrew).

Conklin A. L. 1998. Colonialism and Human Rights, a contradiction in terms? The case of France and West Africa, 1895-1914. American Historical Review, 10(3), 419-442.

Dar, Y. 1968. Hufe'ela Tochnit le Hakalot al ha-Druzim be Ramat ha-Golan (A scheme to alleviate the difficulties of the Druze in the Golan Heights was initiated) Davar, 1 February (Hebrew).

Dar, Y. 1973. Ha-Druzim ve ha-Alawii'im Ba-Golan yishtatfu ba-bhirot la-Histadrut (The Druze and the Alawites in the Golan will participate in trade union elections) Davar, 7 September (Hebrew).

Dayan, H. 2009. Regimes of separation: Israel/Palestine and the shadow of apartheid. In A. Ophir, S. Hanafi \& M. Givoni (Eds.), The Power of Inclusive Exclusion: Anatomy of Israeli rule in the Occupied Palestinian Territories (pp. 281-322). New York: Zone Books.

Doel, M., A., and David, B., C. 1998. Figuring the Holocaust, Singularity and the purification of space. In S. Dalby \& G. Ó. Tuathail (eds), Rethinking Geopolitics, 9-62, London, UK: Routledge.

Eldad, K. 2010. Settlers set up West Bank tourism ventures. Haaretz, 21 April 2010.

Elkins, C., \& Pedersen, S. 2005. Settler colonialism in the twentieth century: Projects, practices. New York, NY, USA: Routledge.

Elkins, C., and Pederson, S., eds. 2005. Settler Colonialism in the Twentieth Century New York, Routledge.

Ennab, W. R. 1994. Population and Demographic Developments in the West Bank and Gaza Strip until 1990, United Nations Conference on Trade and Development, UNCTAD/ECDC/SEU/1: 1-100.

Falah, G. 1991. The facts and fictions of Judaization policy and its impact on the majority Arab population in Galilee. Political Geography Quarterly, 10 (3), 297-316. 
Falah, G. 1996. The 1948 Israeli-Palestinian War and its Aftermath: The Transformation and De-Signification of Palestine's Cultural Landscape. Annals of the Association of American Geographers, 86 (2), 256-285.

Falah, G. 2003. Dynamics and patterns of the shrinking of Arab lands in Palestine. Political Geography, 22 (2), 179-209.

Feige, M. 2009. Settling in the Hearts, Jewish Fundamentalism in the Occupied Territories. Detroit, MI: Wayne State University Press.

Firro, K. 1998. The Druze in the Jewish State: A Brief History. Leiden, Holland: Brill.

Forman, G. and Kedar, A. S. 2004. From Arab Land to Israel Lands', The Legal Dispossession of the Palestinians Displaced by Israel in the Wake of 1948. Environment and Planning D, Society and Space, 22 (6), 809-830.

Foucault, M. 1977. Discipline and Punish, The Birth of the Prison. New York, NY, USA: Random House.

Foucault, M. 2003. Society Must be Defended, New York: Penguin Books.

Foucault, Michel, Michel Senellart, Graham Burchell, François Ewald, and Alessandro Fontana. 2009. Security, Territory, Population: Lectures at the Collège De France 1977--1978. New York: Macmillan.

GA 1969. G2572/2, Financial Survey for the establishment of a ski resort on the Hermon, March 1969.

Gazit, S. 1995. The carrot and the stick, Israel's policy in Judea and Samaria, 19671968. Washington, DC, USA: B'nai B'rith Books.

Golan Archive (GA) 1967. 12041/12 . Preliminary results of the Golan Heights Census, July 1967.

Gordon, N. 2008. Israel's Occupation. Berkeley, CA, USA: University of California Press.

Gordon, N. 2008. Of dowries and brides: A structural analysis of Israel's occupation. Israeli Sociology, 9(2), 271-296 (Hebrew). 
Gordon, N. 2010. Democracy and colonialism. Theory and Event, 13 (2) DOI, 10.1353/tae.0.0138.

Gordon, N. and Cohen, Y. 2012. Western interests, Israeli unilateralism, and the twostate solution. Journal of Palestine Studies, XLI (3): 1-13.

Gorenberg, G. 2006. The Empire, Israel and the Birth of the Settlements, 1967-1977. New York, NY, USA: Times Books.

Gregory, D. 2004. The Colonial Present. Malden, MA, USA: Blackwell.

Haaretz, 1967. Mechalkim Teudot Ba-Rama (giving away identity cards in the 'heights'). Haaretz, 16 August 1967 (in Hebrew).

Hajjar, L. 2005. Courting Conflict: The Israeli Military Court System in the West Bank and Gaza. Berkeley, CA, USA: University of California Press.

Handel, A. 2013. Gated/gating community: The settlement complex in the West Bank. Transactions of the Institute of British Geographers, 39 (4), 504-517.

Harris, W. 1978. War and settlement change, The Golan Heights and the Jordan Rift. Transactions of the Institute of British Geographers, 3 (3), 309-33.

Harris, W. 1980. Taking Root, Israeli Settlement in the West Bank, the Golan, and Gaza-Sinai, 1967-1980. New York, NY, USA: Research Studies Press.

Hatuka, T. 2012. Civilian consciousness of the mutable nature of power: Dissent practices along a fragmented border in Israel/ Palestine, Political Geography 31, 347-357.

ICBS, 2014. Statistical Abstract of Israel, Population by District, Sub-District and Religion, Table 2.15 .

IDFA (Israel Defence Force Archive) 1967a. 68/117/1970. IDFA Weekly reports, 27 July 1967, 13 August 1967, 27 August 1967, 8 September 1967 (Hebrew).

IDFA 1967b. 65/117/1970. The Golan Heights - initial results of the census, 15 August 1967 (Hebrew). 
IDFA 1974. 492/1510/1989. Public opinions regarding settlements in the administered territories the communication centre, Jerusalem Hebrew University October 1974 (Hebrew).

ISA (Israel State Archive) 1967a. Gal 8262/4 letter from Moshe Sela of The Nature Reserves Authority to Colonel Dan Lener of the military northern command, 2 February 1968; letter from officials at the Nature Reserves Authority to the head of the National Antique Division at the Ministry of Culture and Education, 19 December 1967.

ISA 1967b. Gal 8262/4. Letter to the chief supervisor of the survey, 10 December 1967.

ISA 1968. Gal 8262/4. The villages of the Golan, a review of the Golan Regional Team for Landscape and Recreation, undated.

ISA 1969. Gal 17038/20 ISA; Letter from the commander of the Golan Heights military government regarding the question of the return of Syrian resdients to the Golan Heights dated 3 June 1969.

Kaufman, S. J. 2001. Modern Hatreds, The Symbolic Politics of Ethnic War. Ithaca, NY, USA: Cornell University Press.

Khalidi, W., Elmusa, S. S., \& Khalidi, M. A. 1992. All that remains: The Palestinian villages occupied and depopulated by Israel in 1948. Washington, DC, USA: Institute for Palestine Studies.

Kipnis, Y. 2013. The Golan Heights, Political History, Settlement and Geography since 1949. London, UK: Routledge.

Leshem, N. 2013. Repopulating the emptiness: A spatial critique of ruination in Israel/Palestine. Environment and Planning D: Society and Space, 31(3), 522-537.

Levi, S. 1982. Local government in the administered territories. In Judea, Samaria and Gaza, Views on the Present and Future, ed. D. Elazar. Washington, DC, USA: American Enterprise Institute for Public Policy and Research. 
Mann, M. 2005. The Dark Side of Democracy, Explaining Ethnic Cleansing. New York, NY, USA: Cambridge University Press.

Mara'i, T., and Halabi, U. 1992. Life under occupation in the Golan Heights. Journal of Palestine Studies, 22 (1), 78-93.

Mattar, I. 1983. From Palestinian to Israeli: Jerusalem 1948-1982. Journal of Palestine Studies, 12(4), 57-63.

McCarthy, J. 1995. Death and Exile, The Ethnic Cleansing of Ottoman Muslims, 1821- 1922. Princeton, NJ, USA: The Darwin Press.

McGarry, J. 1998. The state-directed movement of ethnic groups as a technique of conflict regulation. Ethnic and Racial Studies, 21(4), 613-638.

Military Orders and Proclamations. 1967-2014. Available online at http://www.law.idf.il/801-he/Patzar.aspx IDF Military Advocate General. (in Hebrew).

Ministry of Agriculture. 1983. Master Plan for Settlement for Judea and Samaria, Development Plan for the Region for 1983 Samaria (Jerusalem, Israel: Ministry of Agriculture, 1983).

Mnookin, R. H., \& Eiran, E. (2005). Discord behind the table: The internal conflict among israeli jews concerning the future of settlements in the west bank and Gaza. Journal of Dispute Resolution, 1(5), 12-44.

Morris, B. 1987. The birth of the Palestinian refugee problem, 1947-1949. Cambridge, UK: Cambridge University Press.

Morris, B. 1988. The Birth of the Palestinian Refugee Problem, 1947-1949. Cambridge, UK: Cambridge University Press.

Murphy, R. and Gannon, D. 2008. Changing the landscape Israel's gross violations of international law in the occupied Syrian Golan. Yearbook of International Humanitarian Law 11, 139-174. 
Naimark, N. M. 2001. Fires of Hatred. Ethnic Cleansing in Twentieth-Century Europe. Cambridge, MA, USA: Harvard University Press.

Nasasra, M. 2012. The ongoing judaisation of the Naqab and the struggle for recognizing the indigenous rights of the Arab Bedouin people. Settler Colonial Studies, 2(1), 81-107.

Newman, D. 1996. The territorial politics of exurbanization: Reflections on 25 years of Jewish settlement in the west bank. Israel Affairs, 3(1), 61-85.

O’Tuathail, G. \& Dahlman, C. 2006. The 'West Bank of the Drina', land allocation and ethnic engineering in Republika Srpska. Transactions of the Institute of British Geographers, 31 (3), 304-322.

O’Tuathail, G. and O’Loughlin, J. 2009. After ethnic cleansing: Return outcomes in Bosnia-Herzegovina a decade beyond war. Annals of the Association of American Geographers, 99 (5), 1045-1053.

Ophir, A., Givoni, M., and Hanafi, S. 2009. Introduction in A. Ophir, M. Givoni \&S. Hanafi, (Eds.), The Power of Inclusive Exclusion, Anatomy of Israeli Rule in the Occupied Palestinian Territories (pp. 15-31). New York, NY, USA: Zone Books.

Pappe, I. (2006). A history of modern Palestine: One land, two peoples. Cambridge, UK: Cambridge University Press.

Pappé, I. 2006. The Ethnic Cleansing of Palestine. New York, NY, USA: One world.

Peace Index, 2012. Jerusalem, Israel: The Israel Democracy Institute.

Peace Now Settlement Watch. NA. Settlements and Outposts. Available online at http://peacenow.org.il/eng/content/settlements-and-outposts.

Peled, Y. and Shafir, G. 2002. Being Israeli the Dynamics of Multiple Citizenship. Cambridge, UK: Cambridge University Press.

Perlmann, J. 2011. The 1967 Census of the West Bank and Gaza Strip, A Digitized Version. Annandale-on-Hudson, N.Y., Levy Economics Institute of Bard College. November 2011 - February 2012. [Digitized from, Israel Central Bureau of 
Statistics, Census of Population and Housing, 1967 Conducted in the Areas Administered by the IDF, Vols. 1-5 (1967-70), and Census of Population and Housing, East Jerusalem, Parts 1 and 2 (1968-70).

http,//www.levyinstitute.org/palestinian-census/ Accessed 17 December 2014.

Petrovic, D. 1994. Ethnic cleansing - an attempt at methodology. EJIL 5, 342-359.

Ram, M. 2014. White but not quite, normalizing colonial conquests through spatial mimicry. Antipode, 46 (3), 736-753.

Ram, M. 2015. Colonial conquests and the politics of normalization: The case of the Golan Heights and Northern Cyprus, Political Geography, 47, 21-32.

Raz, A. 2012. The Bride and the Dowry, Israel, Jordan, and the Palestinians in the Aftermath of the June 1967 War. New Haven and London, NY, USA: Yale University Press.

Rieff, D. 1997. Case study in ethnic Strife, Foreign Affairs, 76 (2), 118-132.

Rishmawi, M. 1987. Planning in whose interest?: Land use planning as a strategy for judaization. Journal of Palestine Studies, 16(2), 105-116.

Robinson, S. 2013. Citizen Strangers, Palestinians and the Birth of Israel's Liberal Settler State. Stanford, CA, USA: Stanford University Press.

Rose, D. B. 1991. Hidden histories: Black stories from Victoria River Downs, Humbert River and Wave Hill Stations, Canterbury: Aboriginal Studies Press.

Roy, S. 1995. The Gaza Strip, The political economy of de-development. Washington, DC, USA: Institute for Palestinian Studies.

Sa'di, A. H. 2013. Thorough surveillance: The genesis of Israeli policies of population management, surveillance and political control towards the Palestinian minority. Manchester, UK: Manchester University Press.

Sa'di, A. H., \& Abu-Lughod, L. 2007. Nakba: Palestine, 1948, and the claims of memory. New York, NY, USA: Columbia University Press. 
Sasson, T. 2005. Report on unauthorized outposts: Submitted to the prime minister. Jerusalem, Israel: Prime Minister office.

Segal, R. \& Weizman, E. 2003. A Civilian Occupation. New York, NY, USA: Verso.

Shai, A. 2006. The fate of abandoned Arab villages in Israel, 1965-1969. History \& Memory, 18 (2), 86-106.

Shalev, M. 1994. Tzar Olami ke-Olam Merkava (My world is as narrow as a Merkava tank). Yediot Achronot, 16 September 1994 (Hebrew).

Shedadah, R. 1985. Occupier's Law, Israel and the West Bank. Washington, DC, USA: Institute for Palestine Studies.

Sjoberg, G., Williams, G., E. N., \& Kuhn, K., E. 1995. Ethics, human rights and sociological inquiry, genocide, politicide and other issues of organizational power. The American Sociologist, Sociology, Law, and Ethics, 26 (1), 8-19.

Smooha, S. 1997. Ethnic democracy: Israel as an archetype. Israel Studies, 2(2): 198241.

Solonari, V. 2010. Purifying the Nation, Population Exchange and Ethnic Cleansing in Nazi-Allied Romania. Washington, DC, USA: Woodrow Wilson Center Press.

Sorkin, M. 2005. Against the Wall: Israel's Barrier to Peace. New York: New Press.

Springer, S. 2009. Culture of violence or violent Orientalism? Neoliberalisation and imagining the 'savage other' in post-transitional Cambodia, Transactions of the Institute of British Geographers, 34, 305-319.

Szanto, E. 2012. Sayyida Zaynab in the state of exception, Shi'i sainthood as 'qualified lLife' in contemporary Syria, International Journal of Middle East Studies, 44 (2), 285-299.

Tyner, J. 2014. Violent erasures and erasing violence: contesting Cambodia's landscapes of Violence, in E. Schindel and P. Colombo (eds), Space and the memories of violence landscapes of erasure, disappearance and exception (pp. 2133), London: Palgrave-Macmillan. 
Tyner, J. Alvarez, G. \& Colucci, A. 2012. Memory and the everyday landscape of violence in post-genocide Cambodia, Social \& Cultural Geography 13(8), 2-19.

Tyner, J. Inwood, J. Alderman, D. 2014. Theorizing violence and the dialectics of landscape memorialization: a case study of Greensboro, North Carolina, Environment and Planning D: Society and Space, 32(5), 902-914.

Tzidkoni, D. 1971. Shney Susim ba-Urva (Two horses in the stable). Davar, 22 June 1971(Hebrew).

United Nations, 1994. Report of the commission of experts established pursuant to United Nations Security Council resolution 780. 27 May 1994 (S/1994/674).

Veracini, L. 2008. Settler collective, founding violence and disavowal: The settler colonial situation. Journal of Intercultural Studies, 29(4), 363-379.

Veracini, L. 2010. Settler colonialism: A theoretical overview. London, UK: Palgrave Macmillan.

Veracini, L. 2011. Isopolitics, deep colonizing, settler colonialism. Interventions, 13(2), 171-189.

Weizman, E. 2007. Hollow Land, Israel's Architecture of Occupation. New York, NY, USA: Verso.

White, K. R. 2009. Scourge of racism: Genocide in Rwanda. Journal of Black Studies, 39 (3), 471-481.

Wolfe, P. 1999. Settler colonialism. London, UK: Continuum.

Wolfe, P. 2006. Settler colonialism and the elimination of the native. Journal of Genocide Research, 8(4), 387-409.

Wood, W. B. 2001. Geographic aspects of genocide, a comparison of Bosnia and Rwanda. Transactions of the Institute of British Geographers, 26 (1), 57-75.

Yiftachel, O. 2006. Ethnocracy, Land and Identity Politics in Israel/Palestine. Philadelphia, PA, USA: Penn University Press. 
Yiftachel, O. \& Rumley, D. 1991. On the impact of Israel's judaization policy in the Galilee, Political Geography Quarterly, 10, 286-296.

Yiftachel, O. \& Segal, M. 1998. Jews and Druze in Israel: State control and ethnic resistance. Ethnic and Racial Studies 21(3),476-506

Yiftachel, O. \& Yacobi, H. 2004. Urban ethnocracy, ethnicization and the production of space in an Israeli 'mixed city'. Environment and Planning D, Society and Space, 21(6), 673-693.

Yishai, Y. 1985. Israeli annexation of East Jerusalem and the Golan Heights, Factors and processes. Middle Eastern Studies, 21(1), 45-60.

Zertal, I and Eldar, A. 2007. Lords of the Land: The War over Israel's Settlements in the Occupied Territories, 1967-2007. New York, NY, USA: Nation Books. 